Сократительная активность детрузора крыс с инфравезикальной обструкцией после введения «Кортексина» и биологически активных продуктов культуры мантийных глиоцитов

\author{
В.Ю. Глоба ${ }^{1}$, Д.Ю. Рудык², С.Г. Али ${ }^{1}$, Г.А. Божок ${ }^{1}$, Е.И. Легач ${ }^{1}$
}

${ }^{1}$ Институт проблем криобиологии и криомедицины НАН Украины, г. Харьков

${ }^{2}$ Харьковский национальный университет им. В.Н. Каразина, г. Харьков

\title{
Contractile Detrusor's Activity in Rats with Bladder Outlet Obstruction After Administration of Cortexin and Biologically Active Productsof Mantle Gliocytes Culture
}

V.Yu. Globa1 ${ }^{1}$, D.Yu. Rudik², S.G. Ali ${ }^{1}$, G.A. Bozhok¹, E.I. Lehach ${ }^{1}$

${ }^{1}$ Institute for Problems of Cryobiology and Cryomedicine of the National Academy of Sciences of Ukraine, Kharkiv, Ukraine

${ }^{2}$ V.N. Karazin Kharkiv National University, Kharkiv, Ukraine

Восстановление поврежденного рецепторного поля вследствие инфравезикальной обструкции (ИВО) актуальная задача урологии. В настоящее время актуален поиск новых форм биологически активных продуктов, полученных путем криодезинтеграции культуры клеток.

Цель работы - исследовать сократительную активность детрузора крыс с инфравезикальной обструкцией после введения кондиционированной среды, полученной от культуры мантийных глиоцитов.

В качестве препарата сравнения использовали препарат «Кортексин», представляющий собой нейропептидный комплекс из мозгового вещества крупных животных. Культуру мантийных глиоцитов (МГ) получали из спинальных ганглиев неонатальных поросят. Клетки высевали в концентрации $5 \times 10^{5}$ кл/мл в чашки Петри («Orange Scientific», Бельгия) и культивировали 20 суток при $37^{\circ} \mathrm{C}, 5 \% \mathrm{CO} 2$. Базовая среда культивирования включала $\alpha$-MEM, $10 \%$ фетальной телячьей сыворотки («BioSera», Франция) и антибиотики. Среду после 20 суток культивирования собирали в стерильные пробирки и аликвотировали по 0,2 мл. Инфравезикальную обструкцию моделировали на 6-месячных белых беспородных крысах-самках лигатурным способом. Через 1,5 месяца лигатуру удаляли и животным в течение 10 дней внутрибрюшинно вводили по 0,2 мл биологически активных веществ. Сократительную активность детрузора (САД) исследовали на изолированных полосках мочевого пузыря по методу F.A. Kullmann и соавт. (2014). Экспериментальных животных распределили по группам: 1 введение «Кортексина»; 2 - введение базовой среды культивирования; 3 - введение кондиционированной среды от МГ; 4 - без лечения; 5 - интактный контроль.

В группах 1 и 4 САД уменьшалась на 51 и $47 \%$ соответственно по сравнению с интактным контролем. Установлено улучшение САД в группе 2 до 90,5\% относительно контроля. В группе 3 САДувеличивалась на $52 \%$ по сравнению с контролем, что можно объяснить появлением дополнительных компенсаторных механизмов.

Результаты эксперимента демонстрируют восстановление САД после введения кондиционированной среды от МГ. Отсутствие значительного эффекта «Кортексина» и позитивное влияние среды от МГ указывают на специфичность нейротропных факторов. Полученные результаты позволяют применять на следующих этапах работы криодезинтегрированные культуры клеток для получения препаратов, обогащенных нейротрофическими факторами.
Restoration of the damaged receptor field due to infravesical obstruction (IVO) is an urgent task of urology. At present, the search for new forms of biologically active products obtained by cryodisintegrating the cell culture is quite important.

The research aim was to investigate the contractile activity of detrusor in rats with infravesical obstruction after administration of conditioned medium obtained from the culture of mantle gliocytes.

As a reference drug we used the Cortexin, which is a neuropeptide complex from the brain substance of large animals. The culture of mantle gliocytes (MG) was obtained from spinal ganglia of neonatal piglets. Cells were plated at a concentration of $5 \times 10^{5}$ cells $/ \mathrm{ml}$ in Petri dishes (Orange Scientific, Belgium) and cultured for 20 days at $37^{\circ} \mathrm{C}, 5 \%$ CO2. The basic culture medium included $\alpha$-MEM, $10 \%$ fetal calf serum (BioSera, France), and antibiotics. After 20 days of culture the medium was collected into sterile tubes and aliquoted to $0.2 \mathrm{ml}$. Infravesical obstruction was simulated by the ligation in 6-month-old white breedless female rats. After 1.5 months, the ligation was removed and $0.2 \mathrm{ml}$ samples of biologically active substances were intraperitoneally injected into the animals during 10 days. The detrusor contractile activity (DCA) was studied in isolated UB-strips according to F.A. Kullmann et al. (2014). Experimental animals were divided into groups: 1 -Cortexin introduction; 2 -introduction of the basic culture medium; 3 - introduction of the conditioned medium from MG; 4 without treatment; 5 - intact control.

In groups 1 and 4, DCA decreased by 51 and 47\%, correspondingly $v s$. the intact control. The improvement of DCA in group 2 was established to be up to $90.5 \%$ of the control level. In group 3, the DCA was increased by $52 \%$ if compared with the control, that can be explained by the appearance of additional compensatory mechanisms.

The results of the experiment demonstrate the restored DCA after the introduction of the MG conditioned medium. The absence of significant effect of Cortexin and the presence of positive effect of the MG conditioned medium indicate the specificity of neurotrophic factors . At the next stages of the research these findings allow the use of cryodisintegrated cell cultures to obtain the preparations enriched with neurotrophic factors. 